\title{
Analisa Teknis dan Ekonomis Pembangunan Kapal Ikan Ukuran 10GT-20GT Konstruksi Fibreglass Reinforced Plastic (FRP) Sesuai Standar Biro Klasifikasi Indonesia
}

\author{
Aryo Baskoro dan Triwilaswandio Wuruk Pribadi \\ Departemen Teknik Perkapalan, Fakultas Teknologi Kelautan, Institut Teknologi Sepuluh Nopember \\ (ITS) \\ e-mail: triwilas@na.its.ac.id
}

\begin{abstract}
Abstrak-Kapal ikan ukuran 10GT-20GT konstruksi fibreglass reinforced plastics yang dibangun untuk menunjang sektor perikanan sebagian besar memiliki sifat mekanik yang rendah pada konstruksi lambung sehingga sering mengalami kerusakan sebelum batas umur konstruksi yang direncanakan. Hal ini disebabkan karena kapal-kapal tersebut dibangun tanpa menerapkan standar susunan laminasi dan fraksi campuran resin dengan serat fibreglass yang benar untuk metode hand lay up agar mampu memenuhi sifat mekanik yang disyaratkan oleh klasifikasi (BKI). Belum adanya standar susunan laminasi dan fraksi resin FRP yang benar menyebabkan standar harga produksi untuk kapal ikan FRP juga belum diketahui. Untuk mengetahui standar komposisi campuran FRP yang benar maka dalam penelitian ini dilakukan pengujian spesimen material FRP meliputi pengujian tarik dan pengujian lentur pada beberapa variasi laminasi. Penentuan variasi laminasi ini berdasarkan pada data dokumen teknis dan observasi di kapangan. Hasil dari pengujian beberapa variasi material FRP dianalisa secara teknis untuk memperoleh susunan laminasi dan fraksi resin material FRP yang benar sehingga memenuhi kriteria sifat mekanik yang disyaratkan oleh BKI. Variasi-variasi laminasi ini kemudian digunakan sebagai dasar perhitungan biaya material sehingga diperoleh korelasi sifat mekanik dengan harga pokok produksi kapal ikan konstruksi FRP. Dari pengujian material diketahui bahwa laminasi yang memenuhi sifat mekanik BKI membutuhkan jumlah serat menerus lebih dari sepertiga jumlah total lapisan dengan berat serat menerus $50 \%$ dari berat total serat. Pada sampel kapal ikan mini purse seine konstruksi FRP ukuran 10GT, apabila menggunakan variasi yang memenuhi BKI maka biaya produksi kasko adalah sebesar Rp 323.370.000,00. Kapal ikan konstruksi FRP ukuran 20GT jika dibangun dengan standar yang sama maka biaya pekerjaan kasko adalah Rp 472.342.175,00.
\end{abstract}

Kata Kunci-Fibreglass Reinforced Plastic (FRP), kapal ikan, metode hand lay up.

\section{PENDAHULUAN}

$\mathrm{P}$ ENINGKATAN kapasitas produksi sektor perikanan di Indonesia diiringi dengan bertambahnya kebutuhan kapal penangkap ikan. Adanya jumlah kebutuhan kapal penangkap ikan yang cukup banyak disertai target waktu untuk pemenuhan kebutuhan tersebut menghasilkan keputusan dipilihnya teknologi pembangunan kapal yang mudah dan membutuhkan tenaga kerja tanpa keahlian khusus. Oleh karena itu, material Fibreglass Reinforced Plastic (FRP) digunakan pada sebagian besar pengadaan kapal-kapal ikan tersebut. Proses produksi yang umum digunakan adalah metode hand lay up, dimana proses laminasi dilakukan secara manual. Proses lay-up ini dilakuan secara berulang hingga laminasi FRP mencapai ketebalan yang diharapkan. Beberapa galangan yang sudah berpengalaman mampu menghasilkan kapal ikan yang baik dan seaworthy, sedangkan kapal ikan yang diporduksi oleh galangan yang kurang berpengalaman umumnya mengalami banyak kendala. Kendala tersebut adalah banyaknya temuan bahwa material FRP untuk konstruksi kapal yang dihasilkan memiiki sifat mekanik yang rendah dan tidak memenuhi standar kekuatan yang telah ditetapkan oleh klasifikasi yang ditunjuk yaitu BKI.

Dari sisi proses produksi kapal, salah satu faktor yang mempengaruhi kegagalan material tersebut adalah kesalahan dalam campuran komposisi material penyusun fiberglass reinforced plastic dikarenakan banyak galangan yang masih belum mengetahui standar komposisi campuran fibreglass agar memenuhi standar sifat mekanik yang ditetapkan oleh BKI. Komposisi campuran tersebut meliputi susunan laminasi serat, jenis resin yang digunakan, perbandingan campuran katalis dengan resin dan perbandingan berat serat dengan berat resin yang diaplikasikan. Faktor lain yang menjadi penyebab dari kegagalan material FRP adalah adanya indikasi digunakannya material subtitusi yang kurang sesuai oleh pihak galangan dalam proses pembangunan kapal FRP. Material subtitusi ini umumnya adalah material yang lebih murah dan digunakan sebagai tambahan atau pengganti serat glass untuk mencapai ketebalan yang disyaratkan, salah satunya adalah pemberian campuran talc atau material subtitusi lainnya dimana materialmaterial ini kurang memberikan kontribusi baik pada sifat mekanik material maupun kekuatan memanjang kapal.

Perbedaan standar produksi kapal ikan konstruksi fiberglass reinforced plastic memiliki dampak pada aspek ekonomis pembangunan kapal FRP. Perbedaan tersebut menyebabkan tidak adanya standar minimal kebutuhan material pembangun dan penilaian harga pokok produksi untuk pembangunan kapal ikan. Dengan adanya permasalahan tersebut maka dalam penelitian ini dilakukan pengujian material untuk beberapa variasi laminasi. Pengujian tersebut meliputi pengujian tarik 
(tensile test) dan pengujian lentur (bending test). Hasil dari pengujian ini adalah menemukan komposisi campuran FRP yang sesuai untuk kapal ikan dan memenuhi sifat mekanik yang disyaratkan oleh BKI, serta campuran FRP lainnya yang tidak memenuhi sifat mekanik tersebut. Hasil pengujian tersebut kemudia menjadi acuan dalam menghitung kebutuhan material utama sehingga diperoleh biaya produksi untuk kapal ikan konstruksi FRP.

\section{A. Dasar Teori dan Studi Literatur}

Kapal ikan berdasarkan jenis alat tangkap yang digunakan umumnya dibedakan menjadi 4 jenis yaitu:

- Kapal ikan jenis trawler

- Kapal ikan jenis purse seine

- Kapal ikan jenis pole and line

- Kapal ikan jenis long line

Komposit adalah material yang tersusun atas campuran dua atau lebih material dengan sifat kimia dan fisika berbeda, dan menghasilkan sebuah material baru yang memiliki sifat-sifat berbeda dengan material-material penyusunnya[1]. Adapun komponen dari material komposit adalah:

1. Material penguat (reinforcement materials), meliputi [2]:

- Serat fibreglass

- Polymer fibres

- Carbon fibres

2. Core material, dimana beberapa material yang dapat digunakan antara lain:

- Balsa

- Thermoset Foams

- Honeycomb

- Core Fabrics

3. Resin, dengan jenis-jenis sebagai berikut [3]:

- Polyester resin

- Vynil ester resin

-Epoxy resin

4. Katalis

5. Gelcoat

Dalam pembuatan kapal berbahan fiberglass terdapat 3 metode laminasi yang sering digunakan di galangan kapal konstruksi FRP. Metode tersebut diantaranya adalah hand lay up, chopper gun dan vacuum infusion [4].

Dalam membangun kapal digunakan rules yang berlaku di area kapal tersebut akan dioperasikan. Tujuan dari penggunaan rules ini adalah untuk menjamin bahwa konstruksi kapal yang dibangun telah memenuhi standar dan kapal tersebut seaworthy [5].

Di Indonesia, rules yang umum digunakan adalah rules yang diterbitkan oleh Biro Klasifikasi Indonesia (BKI). Rules Biro Klasifikasi Indonesia terkait kapal-kapal konstruksi fiberglass antara lain:

> Rules for Non-Metallic Materials, edisi 2014 [6]

$>$ Rules for FRP and Wooden Fishing Vessel up to $24 \mathrm{~m}$, edisi 2015 [7]

$>$ Rules for Fibreglass Reinforced Plastic Ships edisi 2016 [8]

Dalam rules BKI yang telah disebutkan diatas sudah tercantum ukuran-ukuran konstruksi yang disyaratkan, standar kekuatan material fibreglass serta standar pengujian material.
Besarnya kuat tarik material dihitung dengan rumus berikut [9]:

$$
\mathrm{F}=\frac{P}{A}
$$

Dimana: $\mathrm{P}=$ Breaking load $(\mathrm{N})$

$A=$ Luas penampang melintang spesimen $\left(\mathrm{mm}^{2}\right)$

Besarnya modulus elastisitas dapat dihitung dengan rumus berikut:

$$
\mathrm{E}=\frac{P \cdot l}{A \cdot \Delta l}
$$

Dimana: $\mathrm{P}=$ Breaking load $(\mathrm{N})$

A = Luas penampang melintang spesimen $\left(\mathrm{mm}^{2}\right)$

$1=$ Panjang gauge length $(\mathrm{mm})$

$\Delta \mathrm{l}=$ Besarnya elongaton material $(\mathrm{mm})$

Besarnya kuat lentur dapat dihitung dengan rumus berikut:

$$
\mathrm{MOR}=\frac{3}{2} \cdot \frac{P l}{b t^{2}}
$$

Dimana: $\mathrm{P}=$ Breaking load $(\mathrm{N})$

$$
\begin{aligned}
& \mathrm{l}=\text { Panjang gauge length }(\mathrm{mm}) \\
& \mathrm{b}=\text { Lebar spesimen }(\mathrm{mm}) \\
& \mathrm{t}=\text { Tebal spesimen }(\mathrm{mm})
\end{aligned}
$$

Besarnya modulus elastisitas bending dapat dihitung dengan rumus berikut:

$$
\mathrm{MOE}=\frac{\mathrm{l}^{3}}{4 \mathrm{bt}^{3}}\left(\frac{\Delta \mathrm{P}}{\Delta \mathrm{y}}\right)
$$

Dimana: $\mathrm{P}=$ Breaking load $(\mathrm{N})$

1 = Panjang gauge length $(\mathrm{mm})$

$\mathrm{b}=$ Lebar spesimen $(\mathrm{mm})$

$\mathrm{t}=$ Tebal spesimen $(\mathrm{mm})$

$\mathrm{y}=$ Besarnya defleksi pada bagian gauge length

I

Spesimen untuk pengujian tarik disesuaikan dengan standar ISO tentang tensile test (ISO 527-4, test piece III), sebanyak 6 spesimen [10]. Bentuk dan dimensi spesimen tensile test dapat dilihat pada Gambar 1.

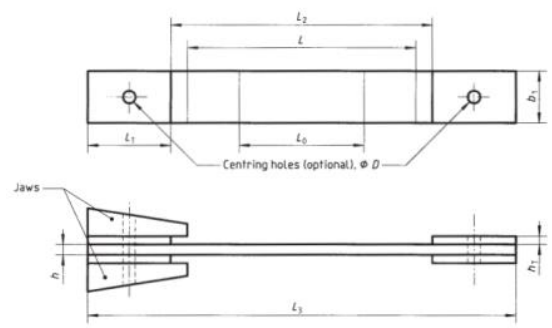

Gambar 1. Desain spesimen uji tarik [ISO 527-4]

Dimana:
$\mathrm{L}_{3}$ Panjang total
$: \geq 250 \mathrm{~mm}$
$\mathrm{L}_{2}$ Jarak antar end tab
$: 150 \pm 1 \mathrm{~mm}$
$b_{1}$ Lebar
h Ketebalan
sampel $\mathrm{L}_{0}$
: $25 \pm 0,5 \mathrm{~mm}$ atau $50 \pm 0,5 \mathrm{~mm}$
: sesuai dengan ketebalan
L Jarak inisial antar grip : $136 \mathrm{~mm}$
$\mathrm{L}_{\mathrm{T}}$ Panjang end tab $: 50 \mathrm{~mm} \pm 1 \mathrm{~mm}$
$\mathrm{h}_{\mathrm{T}}$ Ketebalan end tab $: 1-3 \mathrm{~mm}$
D Diameter centring holes : $3 \pm 0,25 \mathrm{~mm}$

Spesimen untuk pengujian bending menggunakan standar ISO (ISO 14125, Method A) sebanyak 6 spesimen [11]. 
Bentuk dan dimensi spesimen bending test dapat dilihat pada Gambar 2.

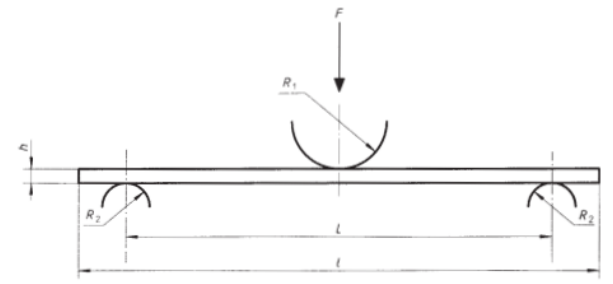

Gambar 2 Desain spesimen uji tekuk [ISO 14125]

Dimana:
$\mathrm{L}_{3}$ Panjang total
$: \geq 250 \mathrm{~mm}$
$\mathrm{L}_{2}$ Jarak antar end tab
$: 150 \pm 1 \mathrm{~mm}$
$b_{1}$ Lebar
h Ketebalan
: $25 \pm 0,5 \mathrm{~mm}$ atau $50 \pm 0,5 \mathrm{~mm}$
$\mathrm{L}_{0}$ Panjang gauge
: ketebalan sampel
L Jarak inisial antar grip : $136 \mathrm{~mm}$
$\mathrm{L}_{\mathrm{T}}$ Panjang end tab $: 50 \mathrm{~mm} \pm 1 \mathrm{~mm}$
$\mathrm{h}_{\mathrm{T}}$ Ketebalan end tab $: 1-3 \mathrm{~mm}$
D Diameter centring holes : $3 \pm 0,25 \mathrm{~mm}$

Berdasarkan rules BKI Fibreglass Reinforced Plastic 2016, hasil dari pengujian FRP yang tersusun atas chopped strand mat dan woven roving tidak boleh kurang dari yang telah ditentukan sebagai berikut:

- Tensile strength $\quad: 98 \quad \mathrm{~N} / \mathrm{mm}^{2}$

- Modulus of tensile elasticity : $6,86 \times 10^{3} \quad \mathrm{~N} / \mathrm{mm}^{2}$

- Bending strength $\quad: 150 \quad \mathrm{~N} / \mathrm{mm}^{2}$

- Modulus of bending elasticity: $6,86 \times 10^{3} \mathrm{~N} / \mathrm{mm}^{2}$

\section{II.URAIAN PENELITIAN}

Dalam penelitian ini dibuat spesimen dengan ketebalan 6 lapis, 7 lapis, 8 lapis, 9 lapis, 10 lapis, 12 lapis dan 14 lapis. Masing-masing ketebalan tersebut dibuat 8 variasi laminasi mulai dari variasi susunan serat, penggunaan resin marine use dan non marine use, campuran talc, dan material subtitusi lain seperti multiplex dan particle board. Variasi-variasi ini dipilih berdasarkan data dokumen tender dan observasi langsung di lapangan. Adapun variasi yang digunakan dalam penelitina ini tampak pada Tabel 1 . Masing-masing variasi dibentuk menjadi 6 (enam) spesimen uji tarik sesuai standar ISO 527-4, dan 6 (enam) spesimen uji lentur sesuai standar ISO 14125.

Tabel 1

\begin{tabular}{cl} 
Variasi spesimen yang dibuat untuk pengujian tarik dan pengujian lentur \\
\hline \hline \multirow{2}{*}{ Variasi } & \multicolumn{1}{c}{ Keterangan } \\
\hline 1 & Laminasi dengan jumlah lapisan Woven Roving < 33\% \\
2 & Laminasi dengan jumlah lapisan Woven Roving $\geq 33 \%$ \\
3 & Laminasi dengan lapisan WR600 dan WR800 \\
4 & Laminasi dengan seluruh lapisan Chopped Strand Mat \\
5 & Laminasi dengan resin non marine use \\
6 & Laminasi dengan campuran talc $( \pm$ 45\% thickness $)$ \\
7 & Laminasi antara FRP dengan multiplex $( \pm 45 \%$ \\
& thickness) \\
& Laminasi antara FRP dengan particle board $( \pm 45 \%$ \\
thickness $)$
\end{tabular}

Hasil dari pengujian ini adalah menemukan komposisi campuran FRP yang sesuai untuk kapal ikan dan memenuhi sifat mekanik yang disyaratkan oleh BKI, serta campuran FRP lainnya yang tidak memenuhi sifat mekanik tersebut. Hasil pengujian tersebut kemudia menjadi acuan dalam menghitung kebutuhan material utama sehingga diperoleh biaya produksi untuk kapal ikan konstruksi FRP.

\section{HASIL DAN PEMBAHASAN}

\section{A. Hasil Pengujian Material FRP}

Dari analisa pengujian dan penggambaran dalam bentuk grafik dapat diketahui tren yang mampu menegaskan variasi laminasi yang benar-benar memenuhi standar sifat mekanik BKI maupun yang tidak memenuhi kriteria tersebut.

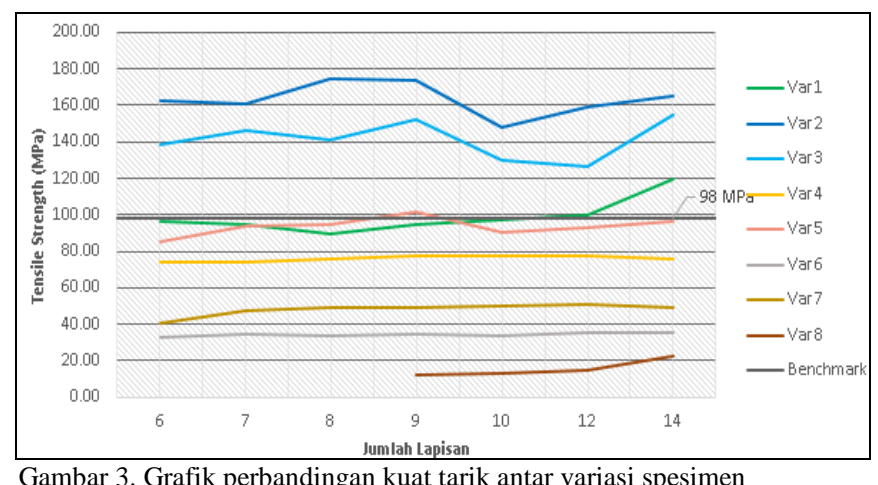

Gambar 3. Grafik perbandingan kuat tarik antar variasi spesimen

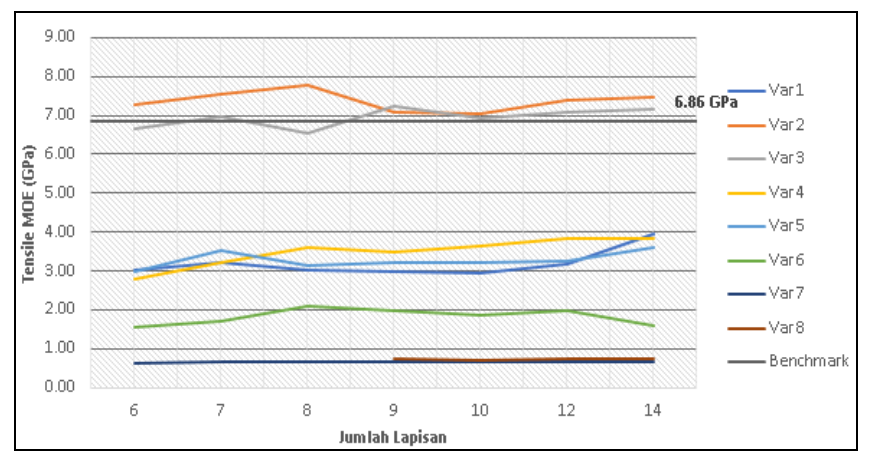

Gambar4. Grafik perbandingan modulus elastisitas kuat tarik antar variasi spesimen

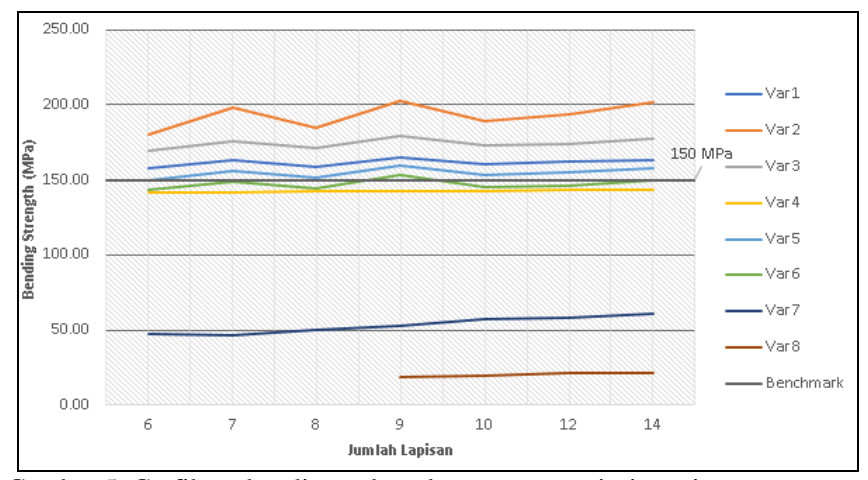

Gambar 5. Grafik perbandingan kuat lentur antar variasi spesimen 


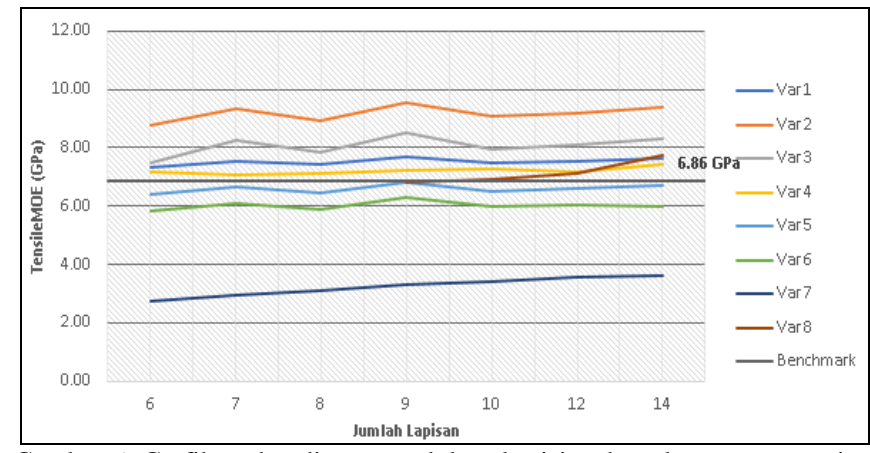

Gambar 6. Grafik perbandingan modulus elastisitas kuat lentur antar varias spesimen

Grafik-grafik yang ditampilkan pada Gambar 3, Gambar 4, Gambar 5 dan Gambar 6 mampu membuktikan bahwa laminasi dengan variasi 2 memiliki sifat mekanik yang disyaratkan oleh BKI Fibreglass Reinforced Plastic Ships edisi 2016. Kuat tarik yang dimiliki laminasi variasi 2 lebih dari $98 \mathrm{MPa}$ dengan modulus elastisitas kuat Tarik diatas 6,86 GPa. Kuat lentur juga menunjukkan nilai yang melebihi standar BKI yaitu diatas $150 \mathrm{MPa}$ serta memiliki modulus elastisitas kuat lentur diatas $6.86 \mathrm{GPa}$

\section{B. Perhitungan Scantling Sampel Kapal Ikan FRP 10GT- $20 G T$}

Tabel 2

Tebal Laminasi Minimum Untuk Konstruksi Kapal Ikan FRP 20GT

\begin{tabular}{lrc}
\hline \hline \multicolumn{1}{c}{ Bagian Kapal } & $\begin{array}{r}\text { Minimal Tebal } \\
\text { Laminasi (mm) }\end{array}$ \\
\hline Lunas & 15 & $\mathrm{~mm}$ \\
Alas & 9.97 & $\mathrm{~mm}$ \\
Sisi samping & 9.5 & $\mathrm{~mm}$ \\
Geladak & 8.20 & $\mathrm{~mm}$ \\
Gading & 5 & $\mathrm{~mm}$ \\
Balok Geladak & 5 & $\mathrm{~mm}$ \\
Pembujur Sisi & 6 & $\mathrm{~mm}$ \\
Pembujur Alas & 5 & $\mathrm{~mm}$ \\
Pembujur Geladak & 5 & $\mathrm{~mm}$ \\
Penegar Sekat dan Tangki & 4 & $\mathrm{~mm}$ \\
Center Girder & 11.00 & $\mathrm{~mm}$ \\
Side Girder & 8.00 & $\mathrm{~mm}$ \\
Side Girder Kamar Mesin & 11.00 & $\mathrm{~mm}$ \\
Floor/Wrang & 6.00 & $\mathrm{~mm}$ \\
Dinding Sekat & 3.79 & $\mathrm{~mm}$ \\
Dinding Tangki & 6.00 & $\mathrm{~mm}$ \\
Bangunan Atas dan Kabin & 5.50 & $\mathrm{~mm}$ \\
Penegar Bangunan Atas & 5.00 & $\mathrm{~mm}$ \\
\hline \hline
\end{tabular}

Perhitungan scantling dalam penelitian ini menggunakan rules BKI Fibreglass Reinforced Platic Ships untuk menentukan ukuran dan ketebalan konstruksi yang digunakan pada kapal ikan ukuran 10GT dan 20GT. Selain perhitungan scantling dilakukan pula perhitungan luas konstruksi yang akan digunakan sebagai dasar perhitungan biaya produksi kapal. Contoh hasil perhitungan scantling ditunjukkan pada Tabel 2.

\section{C.Perbandingan Scantling BKI Fibreglass Reinforced Plastic Ships 2016 dengan Rules Lainnya}

Tabel 3

Perbandingan parameter yang digunakan dalam penrhitungan scantling

\begin{tabular}{lccccc}
\hline \hline & BKI & BKI & & & \\
\multicolumn{1}{c}{ Parameter } & $\mathbf{2 0 1}$ & $\mathbf{2 0 1 5 / G L}$ & DNV & ISO & \\
\hline Dimensi utama & $\mathrm{V}$ & $\mathbf{2 0 0 3}$ & $\mathbf{2 0 1 0}$ & $\mathbf{1 2 2 1 5}$ & FAO \\
Beban yang bekerja & & $\mathrm{v}$ & $\mathrm{v}$ & & $\mathrm{v}$ \\
Sifat mekanik & & $\mathrm{v}$ & $\mathrm{v}$ & $\mathrm{v}$ & \\
Specific gravity & & & & & \\
material & $\mathrm{v}$ & & & & \\
Glass content & $\mathrm{v}$ & & & & \\
Kecepatan dinas & & $\mathrm{v}$ & $\mathrm{v}$ & $\mathrm{v}$ & \\
\hline \hline
\end{tabular}

Secara umum ada 7 parameter yang berpengaruh dalam penentuan ketebalan laminasi. Parameter tersebut antara lain dimensi utama, beban yang bekerja, sifat mekanik material, specific gravity material (untuk menentukan ketebalan tiap layer), glass content, kecepatan dinas, dan total berat serat. Perbandingan parameter antar rules dapat dilihat pada Tabel 3:

Tabel 4

Perbandingan Minimum Thickness dari perhitungan scantling untuk kapal ikan 10GT

\begin{tabular}{|l|c|c|c|c|c|}
\hline \multirow{3}{*}{ Bagian Kapal } & \multicolumn{5}{|c|}{ Minimum Thickness (mm) } \\
\cline { 2 - 6 } & BKI & DNV & $\begin{array}{c}\text { GL } \\
\mathbf{2 0 0 3 / B K I} \\
\mathbf{2 0 1 6}\end{array}$ & ISO & FAO \\
\hline Lunas & 13.8 & - & - & - & - \\
\hline Alas & 7.6 & 9.23 & - & 6.71 & - \\
\hline Sisi samping & 7.2 & 8.72 & - & 4.80 & - \\
\hline Geladak & 7.37 & 6.74 & - & 3.06 & - \\
\hline Dinding Sekat & 3.29 & 6.14 & - & - & - \\
\hline Deckhose & 5.00 & 6.74 & - & - & - \\
\hline Sheer & - & - & - & - & - \\
\hline
\end{tabular}

Tabel 5

Perbandingan Minimum Glass Weight dari perhitungan scantling untuk kapal ikan 10GT

\begin{tabular}{|l|c|c|c|c|c|}
\hline \multirow{4}{*}{ Bagian Kapal } & \multicolumn{5}{|c|}{ Minimum Glass Weight $\left(\mathbf{g r} / \mathbf{m}^{2}\right)$} \\
\cline { 2 - 6 } & BKI & DNV & $\begin{array}{c}\text { GL } \\
\mathbf{2 0 0 3 / B K I} \\
\mathbf{2 0 1 5}\end{array}$ & ISO & FAO \\
\hline Lunas & - & - & 5756.06 & - & 6806.40 \\
\hline Alas & - & - & 3406.58 & 2316.00 & 4106.40 \\
\hline Sisi samping & - & - & 2812.08 & 2007.00 & 4106.40 \\
\hline Geladak & - & - & 1921.92 & 1678.00 & 4106.40 \\
\hline Dinding Sekat & - & - & 2091.41 & - & - \\
\hline Deckhose & - & - & 2645.81 & - & - \\
\hline Sheer & - & - & - & - & 4406.40 \\
\hline
\end{tabular}

Dari Tabel 4 dan Tabel 5 dapat diketahui bahwa untuk kriteria minimum glass weight, rules $\mathrm{FAO}$ adalah yang terberat namun memiliki keunggulan dalam kemudahan perhitungan scantling karena cukup mneggunakan interpolasi. Sedangkan minimum glass weight yang paling ringan diperoleh menggunakan perhitungan scantling menggunakan rules ISO 12215-5. Untuk perhitungan ketebalan minimum, diketahui 
bahwa rules DNV 2.21 Standard for Certification for Craft edisi 2010 lebih tebal daripada BKI FRP Ships edisi 2016 meskipun yang digunakan adalah rumus ketebalan minimum $\left(t_{\min }>t_{p}\right)$, sedangkan rules ISO 12215-5 menghasilkan ketebalan konstruksi yang paling tipis.

\section{D.Analisa Ekonomis}

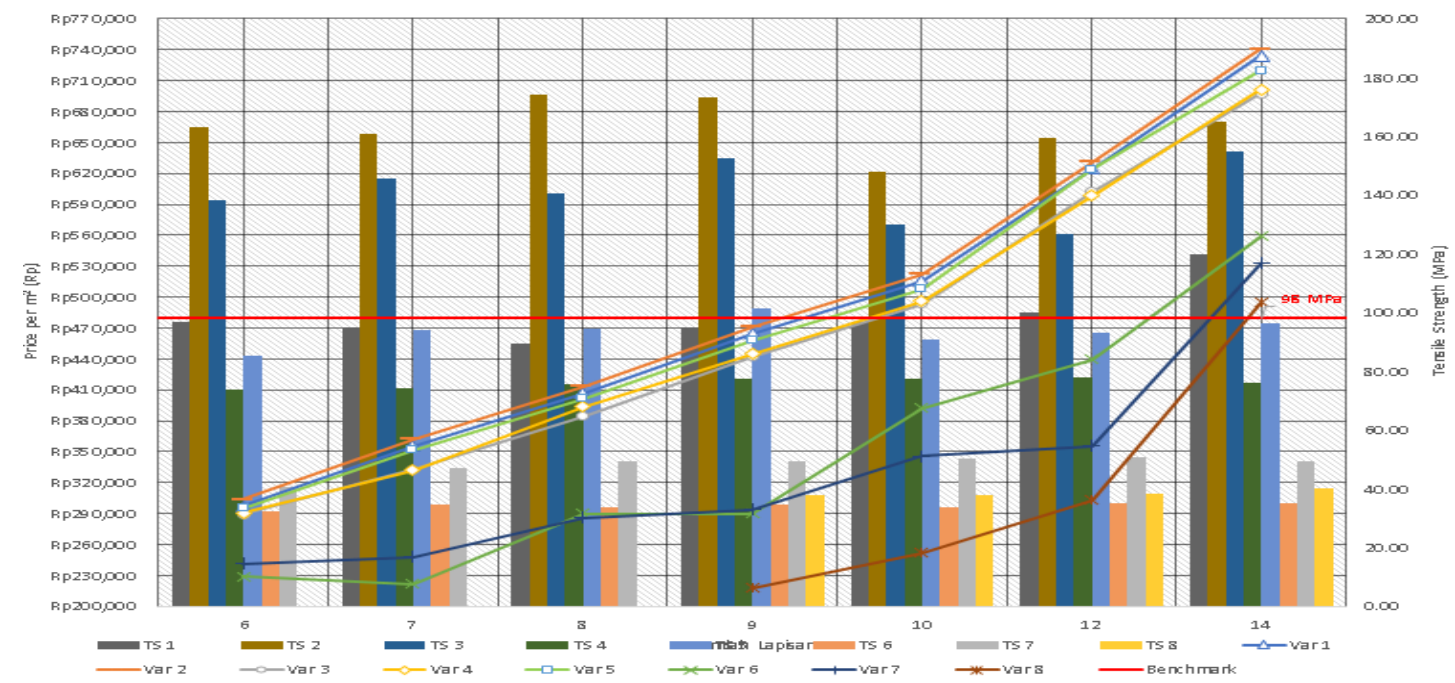

Gambar. 7 Grafik korelasi kuat tarik dengan harga laminasi per meter persegi berdasarkan variasi laminasi

Gambar 7 memaparkan perbedaan harga material jika menggunakan variasi laminasi yang berbeda dan korelasinya dengan salah satu sifat mekanik material yaitu kuat tariknya. Diketahui bahwa variasi laminasi yang memenuhi seluruh kriteria sifat mekanik (variasi 2) memiliki harga material tertinggi per meter perseginya. Sedangkan untuk harga terendah adalah variasi 8 (particle board), diikuti_variasi 7 (multiplex) dan variasi 6 (campuran talc). Masing-masing variasi laminasi tersebut dapat menjadi acuan dalam perhitungan ketebalan laminiasi konstruksi kapal dan biaya produksinya.

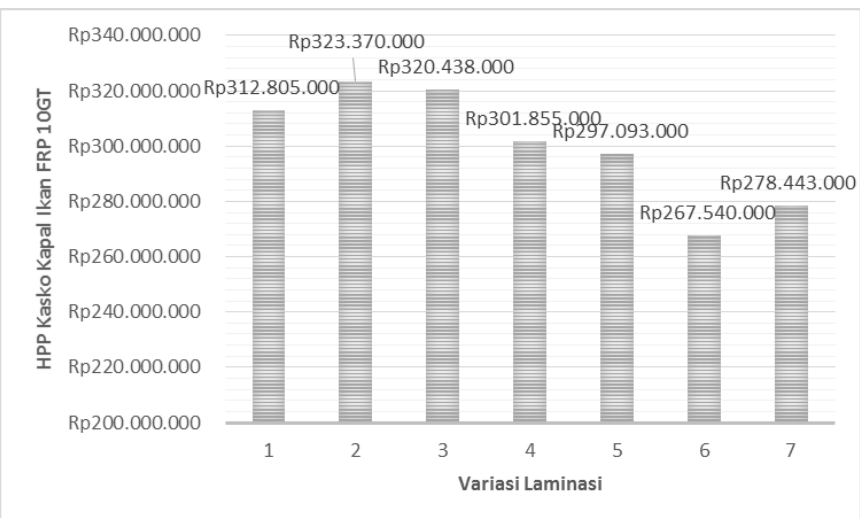

Gambar 8. Grafik perbandingan harga kasko kapal ikan FRP 10GT

Grafik perbandingan harga kasko kapal untuk kapal ikan FRP 10GT ditunjukkan pada Gambar 8. Susunan laminasi variasi 1 hingga variasi 6 diaplikasikan pada seluruh badan kapal, sedangkan variasi 7 (multiplex) terbatas pada konstruksi lambung yang memiliki ketebalan lebih dari $6 \mathrm{~mm}$ (juga tidak termasuk penegar-penegar). Pada sampel kapal ikan konstruksi FRP ukuran 10GT, biaya pekerjaan kasko kapal apabila menggunakan variasi yang memenuhi BKI (variasi 2) adalah sebesar $\mathrm{Rp}$ 323.370.000,00. Jika kapal diproduksi dengan menggunakan resin non marine use (variasi 5) maka biayanya sebesar Rp 297.093.000,00. Kapal ikan 10GT yang diproduksi dengan mengunakan laminasi variasi 1 (resin marine use) memiliki biaya pekerjaan kasko sebesar Rp 312.805.000,00. Untuk variasi 3 jika digunakan akan menghasilkan biaya kasko sebesar Rp 320.438.000,00. Kapal ikan 10 GT dengan variasi laminasi 4 memiliki biaya kasko Rp 301.855.000,00. Apabila kapal dibangun dengan campuran talc (variasi 6) biaya pekerjaan kaskonya adalah Rp 267.540.000,00. Jika laminasi dibuat dengan tambahan multiplex (variasi 7) pada konstruksi lunas, alas, sisi dan geladak maka biaya kasko kapal adalah Rp 278.443.000,00.

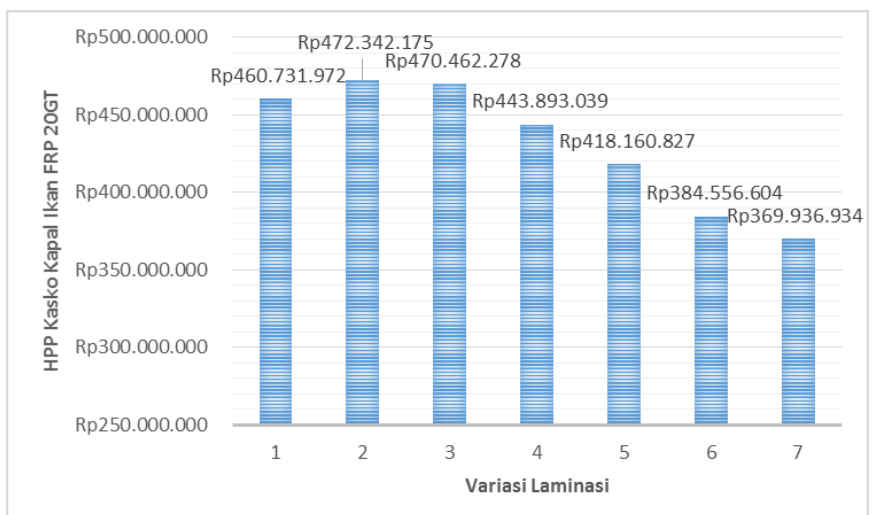

Gambar 9. Grafik perbandingan harga kasko kapal ikan FRP 10GT berdasarkan variasi laminasi 
Perbandingan harga kasko kapal ikan konstruksi FRP ukuran 10GT ditampilakan pada Gambar 9. Susunan laminasi variasi 1 hingga variasi 6 diaplikasikan pada seluruh badan kapal, sedangkan variasi 7 (multiplex) terbatas pada konstruksi lambung yang memiliki ketebalan lebih dari $6 \mathrm{~mm}$ (juga tidak termasuk penegar-penegar). Kapal ikan konstruksi FRP ukuran 20GT jika dibangun dengan variasi laminasi standar BKI (variasi 2) maka biaya pekerjaan kasko adalah $\mathrm{Rp}$ 472.342.175,00. Jika kapal dibangun dengan menggunakan resin non marine use (variasi 5) maka biayanya adalah $\mathrm{Rp}$ 418.160.827,00. Kapal yang dibangun dengan variasi laminasi 3 memiliki biaya pekerjaan kasko kapal sebesar Rp. 470.462.278,00, memiliki selisih yang kurang signifikan dibandingkan dengan kapal yang dibangun dengan variasi laminasi 1 yaitu $\mathrm{Rp}$ 460.731.972,00. Laminasi variasi 4 memiliki biaya kasko yang lebih tinggi dengan variasi 5 (non marine) yaitu Rp 443.893.039,00. Kapal ikan 20GT konstruksi FRP dengan campuran talc (variasi 6) menggunakan resin non marine use biaya kaskonya adalah Rp 384.556.604,00 dan jika menggunakan tambahan multiplex (variasi 7) maka biaya kaskonya adalah Rp 369.936.934,00.

\section{KESIMPULAN}

Setelah dilakukan beberapa perhitungan dan penelitian maka kesimpulan dari Tugas Akhir ini adalah sebagai berikut:

1. Berdasarkan hasil survey dan observasi lapangan, pembangunan kapal ikan konstruksi FRP di Indonesia sebagian besar hanya dapat diketahui pemenuhan standar BKI hanya berdasarkan ketebalan laminasinya. Dari sisi sifat mekaniknya belum dapat dipastikan apakah telah memenuhi kriteria sifat mekanik BKI, sebab terdapat indikasi komposisi laminasi dan campuran FRP yang kurang tepat.

2. Diketahui bahwa untuk mencapai kriteria sifat mekanik yang diharapkan, jumlah serat menerus (continuous fibres) dapat menjadi dasar pertimbangan susunan laminasi, dimana serat menerus yang dgunakan dalam penelitian ini adalah jenis serat Woven Roving. Selain jumlah serat menerus, berat total serat menerus dibandingkan total berat serat secara keseluruhan juga berpengaruh, terutama pada nilai modulus elastisitas kuat tarik. Untuk dapat memenuhi modulus elastisitas yang disyaratkan, berat serat menerus (woven roving) lebih dari 50\% dari total berat serat.

3. Pada sampel kapal ikan mini purse seine konstruksi FRP ukuran 10GT, apabila menggunakan variasi yang memenuhi BKI (sesuai kesimpulan pada poin 1) maka biaya produksi kasko adalah sebesar Rp 323.370.000,00. Kapal ikan konstruksi FRP ukuran 20GT jika dibangun dengan standar yang sama maka biaya pekerjaan kasko adalah Rp 472.342.175,00. Berdasarkan hasil analisa ekonomis biaya produksi kapal ikan mini purse seine ukuran 10GT konstruksi FRP beserta perlekapannya adalah Rp 890.007.000,00, ssedangkan untuk kapal sejenis dengan ukuran 20GT biaya produksinya adalah $\mathrm{Rp}$ 1.261.614.175,00

\section{UCAPAN TERIMA KASIH}

Penulis berterima kasih kepada Bapak Ir. Triwilaswandio Wuruk Pribadi, M.Sc. sebagai dosen pembimbing dan Bapak Dr. Ir. Heri Supomo, M.Sc. yang turut serta memberikan bimbingan dan motivasinya. Terima kasih pula kepada Bapak Imam Baihaqi, S.T., M.T., Bapak Sufian Imam W., S.T., M.Sc. dan Bapak M. Solikhan Arif, S.T., M.T. yang memberikan masukan kepada penulis. Terima kasih kepada Ibu Sri Rejeki Wahyu Pribadi, S.T, M.T. atas segala dukungan kepada penulis. Terima kasih kepada keluarga dan saudarasaudara yang memberikan dukungan kepada penulis.

\section{DAFTAR PUSTAKA}

[1] S. Bader, Composites Handbook. 2005.

[2] E. Greene, Marine Composites. Eric Greene Associates, 1999.

[3] D. Cripps, "Resin Types," 2015. [Online]. Available: http://www.netcomposites.com/guide-tools/guide/resinsystems/resin-types/.

[4] K. Hankinson, Fiberglass Boatbuilding for Amatuers. California: GLEN-L, 1982.

[5] S. S. Committee, Design Guide for Marine Applications of Composites. 1997.

[6] B. K. Indonesia, Rules for Non-Metallic Materials. Jakarta: BKI, 2014.

[7] B. K. Indonesia, Guidance for FRP and Wooden Fishing Vessel Up To 24 m. Jakarta: BKI, 2015.

[8] B. K. Indonesia, Rules for Fiberglass Reinforced Plastic. Jakarta: BKI, 2016.

[9] S. Tsai, Composite Materials: Testing and Design (Fifth Conference). Baltimore: ASTM, 1979.

[10] ISO, Determination of Tensile Properties of Plastics. Berlin: ISO, 1997.

[11] ISO, Fibre Reinforced Plastic Composites: Determi-nation of flexural properties. Berlin, 1998. 